\title{
Molekuláris genetikai vizsgálatok az örökletes endokrinológiai tumor szindrómák klinikai diagnosztikájában
}

\author{
Sarkadi Balázs dr. ${ }^{1,3}$. Grolmusz Vince Kornél ${ }^{1,3}$ \\ Butz Henriett $^{2,3}$. Kövesdi Annamária ${ }^{1,3}$. Likó István ${ }^{3}$. Nyirő Gábor ${ }^{3,4}$ \\ Igaz Péter dr. ${ }^{1,4}$. Patócs Attila dr. ${ }^{1,2,3}$ \\ Semmelweis Egyetem, Általános Orvostudományi Kar, ${ }^{1}$ II. Belgyógyászati Klinika, \\ ${ }^{2}$ Laboratóriumi Medicina Intézet, Budapest \\ ${ }^{3}$ Magyar Tudományos Akadémia-Semmelweis Egyetem, \\ „Lendület” Örökletes Endokrin Daganatok Kutatócsoport, Budapest \\ ${ }^{4}$ Magyar Tudományos Akadémia-Semmelweis Egyetem, Molekuláris Medicina Kutatócsoport, Budapest
}

\begin{abstract}
Az örökletes endokrinológiai tumor szindrómák, vagy multiplex endokrin neoplasiák (MEN) közös jellegzetességei a különböző endokrin szervek daganatainak társulása egy betegben vagy egy családon belül. A MEN-szindrómáknak több altípusát különböztethetjük meg, amelyek közül az l-es és a 2-es típus a leggyakoribb. Öröklődésük az autoszomális domináns jelleget követi, az érintett családokban 50\%-os az átörökítés valószínúsége. A MEN-szindrómák mellett a sporadikus megjelenésű endokrin daganatok genetikai hátterében is igazolhatók a MEN-szindrómákért felelős gének eltérései, és a később MEN-szindrómásnak bizonyuló esetek zöme is sporadikus formaként kerül felismerésre. A molekuláris genetikai diagnosztika elsődleges szerepe ezekben a szindrómákban a betegségért felelős eltérés kimutatása, majd genetikai tanácsadást követően az érintett családokban genetikai szürővizsgálatok végzése. A vizsgálat után a tünetmentes, de a mutációit hordozó egyének folyamatos klinikai nyomon követésével a daganatok morbiditásának megelőzése, csökkenése érhető el. Az utóbbi évek technológiai fejlődésével átalakult az örökletes kórképek molekuláris genetikai diagnosztikája is. Az új generációs szekvenálásnak a klinikai munkában történő elterjedésével az endokrindaganat-szindrómákban is bővült a vizsgálandó gének száma. A jelen összefoglalóban áttekintjük az örökletes endokrin tumor szindrómák genetikai hátterét, és bemutatjuk a jelenleg is alkalmazott molekuláris biológiai vizsgálómódszereket.
\end{abstract}

Orv Hetil. 2018; 159(7): 285-292.

Kulcsszavak: örökletes tumorszindrómák, mellékpajzsmirigy, phaeochromocytoma, mutáció, szekvenálás

\section{Evolution of molecular genetic methods in the clinical diagnosis of hereditary endocrine tumour syndromes}

\footnotetext{
The common features of hereditary endocrine tumour syndromes or multiple endocrine neoplasias (MEN) are the association of various tumours of different endocrine organs in one patient or within the same family. Different types can be distinguished from among which type 1 and type 2 are the most common. The mode of inheritance is autosomal dominant, meaning that there is a $50 \%$ chance to inherit the pathogenic alteration. The pathogenic variants of genes responsible for MEN syndromes have also been identified in sporadic endocrine tumours and many cases initially referred to as sporadic have been later categorized as familiar based on genetic analysis. The main role of the molecular genetic analysis in these syndromes is to identify the pathogenic variant, then, after appropriate genetic counseling, to perform the genetic screening of first-degree relatives. Following molecular genetic analysis, the stateof-the-art clinical follow-up of the clinically healthy mutation carriers may decrease or even prevent the morbidity and mortality. Due to technological developments in recent years, the molecular genetic analysis of hereditary tumour syndromes has also been changed. Using next generation based sequencing methods in routine clinical diagnostics,
} 
the number of pathogenic genes in endocrine tumours has also increased. The present review focuses on the genetic background of hereditary endocrine tumour syndromes and the recently used molecular biological methods will also be presented.

Keywords: hereditary endocrine tumour syndromes, parathyroid gland, phaeochromocytoma, mutation, sequencing

Sarkadi B, Grolmusz VK, Butz H, Kövesdi A, Likó I, Nyirő G, Igaz P, Patócs A. [Evolution of molecular genetic methods in the clinical diagnosis of hereditary endocrine tumour syndromes]. Orv Hetil. 2018; 159(7): $285-292$.

(Beérkezett: 2017. december 30.; elfogadva: 2018. január 18.)

\begin{abstract}
Rövidítések
AIP = aril kölcsönható (interacting) fehérje; CaSR = kalciumérzékelő receptor; $\mathrm{CDKN} 1 \mathrm{~B}=$ ciklinfüggókináz-inhibitor-1B EPASI = endothelialis PAS domén fehérje- $1 ; \mathrm{FH}=$ fumarát hidratáz; $\mathrm{FHH}=$ familiaris hypocalciuriás hypercalcaemia; FIPA = familiaris izolált hypophysisadenoma; FMTC $=$ familia ris medullaris pajzsmirigy-carcinoma; GCM2 = gliasejt hiányzó homológ-2; GOT2 = glutamin-oxálecetsav-transzamináz; KIF1B = a kinezincsalád 1B-tagja; MAX = MYC-hez kapcsolódó faktor-X; MDH2 = malát-dehidrogenáz-2; MEN = multiplex endokrin neoplasia; MLPA = multiplex ligatióspróbaamplifikáció; $\mathrm{MTC}=$ medullaris pajzsmirigyrák; NF1 = neurofibromatosis l-es típusa; NGS = új generációs szekvenálás; $\mathrm{PCR}=$ polimeráz-láncreakció $; \mathrm{PGL}=$ paraganglioma; Phaeo $=$ phaeochromocytoma $;$ PHD2 $=$ propil-hidroxiláz - do mént tartalmazó fehérje-2; PTEN = foszfatáz- és tenzinhomológ; PTH = parathormon; RET = transzfekció során újraszerveződő fehérje; SDH = szukcinát-dehidrogenáz; SDHA = szukcinát-dehidrogenáz A-alegysége; SDHAF2 = szukcinátdehidrogenáz AF2-alegysége; $\mathrm{SDHB}=$ szukcinát-dehidrogenáz B-alegysége; SDHC = szukcinát-dehidrogenáz C-alegysége; $\mathrm{SDHD}=$ szukcinát-dehidrogenáz $\mathrm{D}$-alegysége; TGF $\beta$ = tumornövekedési faktor-béta; TMEM127 = transzmembránprotein-127; VHL = von Hippel-Lindau
\end{abstract}

A molekuláris genetikai vizsgálómódszerek fejlődése, ezek elérhetősége és a klinikai genetikai diagnosztikában történő térhódítása átalakította az örökletes endokrinológiai szindrómák molekuláris genetikai diagnosztikáját is. Az új generációs szekvenáláson alapuló vizsgálómódszerek térhódítása a diagnosztikában több olyan új kihívást is jelentett és jelent napjainkban is, amelyek megoldása multidiszciplináris megközelítést tesz szükségessé. A szakorvosok mellett molekuláris biológusok, bioinformatikusok és laboratóriumi szakemberek együttes munkájára van szükség a megfelelő ellátás biztosításához. A vizsgálatok indikációja, a klinikai diagnózis felállítása mellett a vizsgálatok során keletkezett adatmennyiség feldolgozása és interpretálása is kihívásokkal teli [1]. A humángenetikai társaságok szakmai ajánlásai is kiemelik, hogy minden olyan egyén esetében, akinél 10\%-nál nagyobb az örökletes daganatok kialakulásának veszélye, javasolt a genetikai vizsgálat [2]. Ez a hormonrendszert érintő tumorokra is igaz, hiszen a legtöbb, még a sporadikus megjelenést mutató esetek között is magas a csí- rasejtes géneltérések előfordulása [3]. Természetesen a megnövekedett igény és a módszerek elérhetősége is hozzájárult a vizsgálatok elterjedéséhez.

A molekuláris genetikai diagnosztikai munka átalakult; a korábbi egy eltérés-egy gén koncepcióról váltva, napjainkban géncsoportokat vagy teljes genomot célzó vizsgálatokat végeznek. Természetesen a módszertani fejlödés maga után vonja az egyéb területek fejlődését is. A genetikai tanácsadástól és a speciális beteg-beleegyező nyilatkozatok kialakításától kezdve az elvégzett mérések adatainak tárolásán, felhasználásán át a vizsgálati lelet kiadásáig, minden folyamatnak szabályozottnak, ellenőrzöttnek kell lennie [2].

Az örökletes endokrinológiai tumor szindrómák, vagy multiplex endokrin neoplasia (MEN-) szindrómák során a hagyományos és az új generációs szekvenálási módszerek természetesen egymást kiegészítve kerülnek alkalmazásra. A jelen tanulmányban a szerzők bemutatják, hogyan történik a különböző metodikák ötvözése, amelyek szükségesek ahhoz, hogy a klinikai igényeknek megfelelő vizsgálati eredmények kerüljenek meghatározásra a hormonrendszert érintő daganatok molekuláris genetikai diagnosztikájában.

\section{MEN-szindrómák genetikai vizsgálata hagyományos molekuláris genetikai módszerekkel}

\section{MEN1-szindróma}

A MENl-szindróma (Wermer-kór) (OMIM 131100) három fó manifesztációja a primer, általában többszörös mellékpajzsmirigy-adenoma, az enteropancreaticus neuroendokrin daganat és a hypophysisadenoma [4]. A MEN1-szindróma klinikai diagnózisa kimondható, ha a 3 fökomponens közül legalább 2 jelen van egy betegben. MENl-szindrómás családnak tekintjük azt a családot, amelyben legalább egy MENl-szindrómás családtagon kívül legalább egy elsőfokú vérrokon családtagban a 3 fó MENl-komponens közül legalább 1 előfordul. Fontos megfigyelés, hogy a mutációk egy része de novo alakul ki, ezért a negatív családi anamnézis nem zárja ki a MENlszindróma lehetőségét [5]. A MENl-szindróma gyanúja 
akkor megalapozott, ha bármely fó daganattípus fiatal korban (<35 év) vagy multiplex formában fordul elő [5]. Klinikai MEN1-diagnózis esetén 80-90\%-ban lehet igazolni molekuláris genetikai vizsgálattal a csírasejtes betegségokozó MEN1-gén-mutációt.

A genetikai vizsgálat legfontosabb eredménye a MENl-szindrómás családokban a klinikai tüneteket még nem mutató, de betegséget okozó mutációt hordozó családtagok azonosítása. A negatív genetikai eredmény mentesíti a családtagokat a további felesleges klinikai, laboratóriumi és képalkotó vizsgálatoktól. A betegségokozó géneltérések a menint kódoló $M E N 1$-gén teljes szakaszán kimutathatók. Nincs mutációs hot spot, és majdnem minden MENl-szindrómás családnak egyedi mutációja van $[4,5]$. A mutációk típusa alapján a fehérje teljes hiányát előidéző stop kodont vagy kereteltolódást okozó mutációk gyakoriak MENl-ben. Ezek patogenitása nem kérdőjelezhető meg. Az aminosavcseréhez vezető, miszszensz mutációk esetében a patogenitás bizonyításához a pontos genotípus-fenotípus összefüggések mellett a mutáció szegregációja az elváltozással és az adott génvariáns előfordulási gyakoriságának ismerete szükséges ahhoz, hogy a patogenitás egyértelműen bizonyítható legyen.

A molekuláris genetikai vizsgálat alapja a hagyományos Sanger-alapú DNS-szekvenálás, amellyel a MEN1gén teljes kódoló szakaszait polimeráz-láncreakcióval (PCR) történő amplifikációja után végeznek el. A Sanger-szekvenálás mellett ugyanakkor szükséges a $M E N 1$ gén vizsgálatát elvégezni olyan módszerrel is, amellyel a gén nagyobb szakaszainak heterozygota deletióit is ki lehet mutatni [6]. Ilyen módszer a multiplex ligatióspróba-amplifikáció (MLPA). Az összes MENl-szindrómát okozó betegséghez vezető génvariáns közül 1-2\%-nak az igazolásához szükséges az MLPA-módszer.

Laboratóriumunkban a 2000-es évek elejétól érhető el a MEN1-gén vizsgálata. Eddig közel 300 esetben került sor a MEN1-gén vizsgálatára olyan betegekben, akiknél a klinikai megjelenés alapján felmerült a MENl-szindróma lehetősége. Ezek közül 26 indexbeteg esetében igazoltuk a betegségért felelős $M E N 1$-mutációt. A mutációkra jellemző, hogy minden család egyedi mutációt hordozott, nem igazolódott alapító mutáció a hazai beteganyagban. A mutációk többsége stop kodont vagy kereteltolódást okozó rövid deletio vagy inszerció volt [7]. A genotípus-fenotípus összefüggések során a betegekben mindhárom fó manifesztáció kb. egyenlő arányban fordult elő, így a gastroenteropancreaticus neuroendokrin daganatok és a hypophysisadenomák sem voltak ritkábbak a primer hyperparathyreosist okozó mellékpajzsmirigy-adenomáknál.

\section{MEN2-szindróma}

A multiplex endokrin neoplasia 2-es típusában (MEN2) a leggyakoribb daganat a medullaris pajzsmirigyrák (MTC), amely a mutációt hordozó betegekben a 40 éves életkor eléréséig csaknem minden esetben kialakul.
Phaeochromocytoma (Phaeo) a MEN2-esetek kb. felében, míg mellékpajzsmirigy-adenoma a betegek 1020\%-ában fordul elő. A klinikai tünetek alapján három altípus különíthető el; a MEN2A-ban mindhárom elváltozás megjelenik, a MEN2B-ben a mellékpajzsmirigyek nem érintettek, de az MTC és a Phaeo mellett jellegzetes testalkat, marfanoid habitus, csontrendszeri rendellenességek, nyálkahártya-neuromák, a corneaidegek megvastagodása és pubertas tarda figyelhető meg. Az MTC önállóan megjelenő formáját az ún. familiaris medullaris pajzsmirigy-carcinoma (FMTC) jelenti, ebben az alcsoportban semmilyen más MEN2-re jellemző elváltozás nem mutatható ki [8].

A MEN2-szindróma is autoszomális domináns módon öröklődik, kialakulásáért a RET-protoonkogén csírasejtes mutációi felelősek. A gén a $10 q 11.2$ locuson található, 55 kb nagyságú, és 22 exonból áll. A RET-fehérje egy receptor-tirozinkináz-TGF $\beta$-szupercsaládba tartozó transzmembránfehérje; az extracellularis rész tartalmazza a cadherinkötő doméneket, melyeknek a jelátvitelben van jelentóségük, valamint az ún. ciszteinben gazdag régiót, melynek a receptordimerizációban van szerepe [8].

A RET-gént érintő mutációkat két nagy csoportba sorolhatjuk; az első csoportba tartozók a RET inaktiválódását okozzák, és a Hirschprung-betegség patogenezisében játszanak szerepet, míg a második csoportba tartozók a RET ligand nélküli aktiválódását váltják ki. Az utóbbi csoportba sorolt ún. aktiváló mutációk játszanak szerepet a MEN2-tumorok patogenezisében. Ezek a mutációk az extracellularis ciszteinben gazdag régió mutációi, s a RET-receptor aktivációját okozzák. Szemben a MEN1-mutációkkal, a RET-génben van mutációs hot spot. A 634-es kodon mutációi a RET ligand nélküli homodimerizációját és következményes tirozinkináz-aktiválódást idézik elő [8].

Az összes MEN2-szindrómás beteg 90-95\%-ában mutatható ki RET-mutáció. Szoros genotípus-fenotípus összefüggések ismertek, amelyek alapján az MTC prevenciójában elsődleges szerepű preventív pajzsmirigy-eltávolítás időpontja is mutációspecifikusan ajánlott [9].

Klinikánkon a RET-protoonkogén molekuláris genetikai vizsgálata 1997-ben került bevezetésre [10]. Jelenleg mintegy 100 mutációhordozó áll gondozás alatt [11, 12].

A RET-gén vizsgálata - a MEN1-szindrómához hasonlóan - hagyományos módszerekkel történik, elsősorban a 8-16-os exonok elemzésével, de a klinikai képtől függően a 10-16-os exonok vizsgálata minden klinikailag igazolt MTC esetében indokolt [9]. Az új generációs szekvenálást használó laboratóriumokban is elérhető a RET-gén vizsgálata, majdnem minden gyártó onkológiai paneljében jelen van a gén. A csírasejtes mutáció vizsgálata mellett a RET-gén vizsgálatának indikációját jelentheti a $R E T$-gén szomatikus mutációjának azonosítása sporadikus MTC-ben is. Amennyiben a tumorszövetben kimutatható RET-mutáció, célzott, specifikusan RET-ti- 
rozinkináz-gátló kezelés is javasolható lehet. Jelenleg a vandetanibbal és a kabozantinibbel kapcsolatos klinikai vizsgálatok folyamatban vannak [9].

A pajzsmirigy nem medullaris rákjainak esetében ritka az örökletes genetikai hibák előfordulása. A follicularis pajzsmirigyrák a Cowden- és a Bannayan-Riley-Ruvalcaba-szindrómák részjelensége lehet. Ezek a kórképek csírasejtes PTEN-mutációkhoz társulnak. A pajzsmirigyrák mellett egyéb daganatok (emlőrák, trichilemmoma, lipomatosis, endometriumrák) és specifikus fenotípusjegyek (hemihipertrófia, pettyezett glans penis) fordulnak elő. A diagnózist a PTEN-gén hagyományos molekuláris biológiai módszerekkel történő vizsgálata támasztja alá.

\section{Egyéb csírasejtes génmutációk szerepe MEN1-hez hasonló klinikai képet mutató szindrómákban}

A mellékpajzsmirigy-adenomák genetikai hátterében több új gén szerepére derült fény. Ezek közül az egyik legjelentősebbnek tünő a $C D K N 1 B$, amelynek csírasejtes mutációit igazolták olyan $M E N 1$-negatív betegekben, akikben mellékpajzsmirigy-adenoma és hypophysisdaganatok alakultak ki. A CDKNIB szerepe először patkányban került igazolásra: a mutációt hordozó állatokban a MENl-szerû fenotípus manifesztálódott több szerv érintettségével. A szakirodalom MEN4-szindrómának hívja a $C D K N 1 B$-mutációkhoz társult kórképet. $\mathrm{Az}$ utóbbi évek kutatásai kimutatták, hogy sporadikus megjelenésû primer hyperparathyreosisban, a vékonybél neuroendokrin daganataiban, lymphomákban és az emlő daganataiban is azonosítottak $C D K N 1 B$-mutációkat, ami alátámasztja ennek a génnek a tumorszuppresszori szerepét [13].

Önálló szindróma az ún. mellékpajzsmirigy-állkapocs tumor szindróma, amelynek hátterében a CDC73 (HRPT2)-gén mutációi állnak. A szindrómát a MEN1szindrómától elkülöníti az a megfigyelés, hogy CDC73mutációk esetében a mellékpajzsmirigy-daganat rosszindulatú, míg MEN1-szindrómában a daganatok jóindulatúak. A mellékpajzsmirigy-állkapocs tumor szindróma fiatalabb életkorban jelentkezik, és a betegek gyakrabban szorulnak onkológiai kezelésre, mint MEN1-szindróma esetén [14].

Kétezer-tizenhatban azonosították a GCM2 transzkripciós faktort kódoló gént, amelynek két génvariánsát összefüggésbe hozták a familiaris primer mellékpajzsmirigy-adenomák kialakulásával [15]. A tanulmányban a MEN1- és a MEN4-negatív eseteket vizsgálták, és az összes eset 18\%-ában azonosították a c.1136T>A (p.Leu379Gln) és a c.1181A>C (p.Tyr394Ser) variánst. Funkcionális vizsgálatokkal bizonyították, hogy ezek a génvariánsok evolúciósan konzervált doménekben helyezkednek el; a mutált aminosavak fokozott transzkripcionális aktivitást idéztek elő a vad típusú fehérjéhez viszonyítva. Mindezek alapján a GCM2-gén vizsgálata is indokolt mellékpajzsmirigy-adenomás betegekben. Ugyanakkor a misszensz variánsok patogenitásának bizonyítása nehéz: több esetben a korábban kimutatott variánsokról is a későbbi adatok igazolják, hogy viszonylag gyakori eltérések, amelyek patogenetikai szerepe csak egyes populációkban vagy csak bizonyos körülmények között manifesztálódik. Egy friss tanulmány is kimutatta, hogy a két GCM2-gén-variáns allélgyakoriságai különbözőek voltak a különböző népcsoportokban, felvetve, hogy az igazolt összefüggések csak bizonyos populációkban relevánsak [16].

A primer mellékpajzsmirigy-adenomákban a megemelkedett PTH differenciáldiagnosztikai szempontjából fontos tisztázni, hogy az emelkedett PTH-koncentráció mögött nem familiaris hypocalciuriás hypercalcaemia $(\mathrm{FHH})$ áll. Ezt a legkönnyebben a szérum- és vizeletkalcium-ürítés mértékének meghatározásával lehet elérni. $\mathrm{FHH}$-ban a vizelet kalciumclearance-kreatininclearance aránya kisebb, mint 0,01, míg primer hyperparathyreosisban ez magasabb, mint 0,02 . FHH-s betegben a mellékpajzsmirigyek eltávolítása nem indokolt, míg primer hyperparathyreosisban vagy MENl-szindrómában a mellékpajzsmirigyek sebészi eltávolítása a választandó kezelés [17]. Genetikai szempontból az FHH hátterében a kalciumérzékelő receptort (CaSR) kódoló gén mutációi felelősek, így a CaSR molekuláris genetikai vizsgálata szintén indokolt lehet primer hyperparathyreosisban, elsősorban az újszülöttkorban jelentkező esetekben [18].

Módszertani szempontból így megállapítható, hogy a primer hyperparathyreosisban szenvedő betegek esetében indokolt a $M E N 1$-, CDKN1B-, CDC73-, GCM2- és CaSR-gén vizsgálata, amelyek labortechnikai szempontból már elörevetítik azt, hogy új generációs szekvenálással vizsgálható specifikus génpanel is bevezetésre kerülhet a klinikai gyakorlatba.

Egy családon belül halmozott előfordulású hypophysisdaganatok esetében a MENl-szindróma mellett az ún. familiaris izolált bypophysisadenoma (FIPA: familial isolated pituitary adenoma) szindróma is elöfordulhat. Ezekben az esetekben indokolt az $A I P$ - (aryl interacting protein) gén vizsgálata. $A I P$-mutációkhoz társulva a leggyakrabban növekedési hormont termelő daganatok, de prolactinomák és ritkán hormonálisan inaktív hypophysisdaganatok is kialakulhatnak. A genetikai vizsgálat során az AIP-gént PCR-t követő Sanger-szekvenálással és MLPA-módszerrel elemzik.

\section{Örökletes phaeochromocytoma/ paraganglioma szindróma molekuláris genetikai vizsgálata, a hagyományos és új generációs szekvenálási technológiák ötvözése}

A phaeochromocytomák (Phaeo) és paragangliomák (PGL) a mellékvesevelő, illetve a szimpatikus és paraszimpatikus dúclánc kromaffin sejtjeiből kiinduló, ritka 
1. táblázat |Az örökletes endokrin tumorszindrómák kialakulásáért felelős gének és a vizsgálatokra javasolt módszerek

\begin{tabular}{|c|c|c|}
\hline Örökletes tumorszindróma & Gén & Vizsgálati módszer \\
\hline Multiplex endokrin neoplasia l-es típusa & $M E N 1$ & $\begin{array}{l}\text { A teljes kódoló szakasz PCR-t követő Sanger-szekvená- } \\
\text { lással és MLPA-val }\end{array}$ \\
\hline Multiplex endokrin neoplasia 2-es típusa & $R E T$ & $\begin{array}{l}\text { A 8-16. exon PCR-t követő Sanger-szekvenálással } \\
\text { *új generációs szekvenálással, onkológiai génpanelekben } \\
\text { elérhető }\end{array}$ \\
\hline Multiplex endokrin neoplasia 4-es típusa & $C D K N I B$ & $\begin{array}{l}\text { A teljes kódoló szakasz PCR-t követő Sanger-szekvená- } \\
\text { lással és MLPA-val }\end{array}$ \\
\hline Mellékpajzsmirigy-állkapocs tumor szindróma & CDC73 & $\begin{array}{l}\text { A teljes kódoló szakasz PCR-t követő Sanger-szekvená- } \\
\text { lással és MLPA-val }\end{array}$ \\
\hline Familiaris primer mellékpajzsmirigy-adenoma & $M E N 1$, GCM2, CaSR & $\begin{array}{l}\text { A teljes kódoló szakasz PCR-t követő Sanger-szekvená- } \\
\text { lással } \\
\text { *két variáns vizsgálata egyéb módszerekkel is javasolt }\end{array}$ \\
\hline Familiaris izolált hypophysisadenoma & $A I P$ & $\begin{array}{l}\text { A teljes kódoló szakasz PCR-t követő Sanger-szekvená- } \\
\text { lással és MLPA-val }\end{array}$ \\
\hline $\begin{array}{l}\text { Cowden-kór és Bannayan-Riley-Ruvalcaba- } \\
\text { szindróma }\end{array}$ & PTEN & $\begin{array}{l}\text { A teljes kódoló szakasz PCR-t követő Sanger-szekvená- } \\
\text { lással és MLPA-val }\end{array}$ \\
\hline Von Hippel-Lindau-szindróma & $V H L$ & $\begin{array}{l}\text { A teljes kódoló szakasz PCR-t követő Sanger-szekvená- } \\
\text { lással és MLPA-val } \\
\text { *új generációs szekvenálással, onkológiai génpanelekben } \\
\text { elérhető }\end{array}$ \\
\hline Neurofibromatosis l-es típusa & $N F 1$ & $\begin{array}{l}\text { Elsősorban új generációs szekvenálással és az azonosított } \\
\text { eltérések validálása Sanger-szekvenálással }\end{array}$ \\
\hline $\begin{array}{l}\text { Örökletes phaeochromocytoma/paraganglioma } \\
\text { szindróma }\end{array}$ & $\begin{array}{l}\text { SDHA, SDHAF2, SDHB, } \\
\text { SDHC, SDHD, FH, MDH2, } \\
\text { GOT2, TEM127, MAX, NF1, } \\
\text { VHL, EPAS1, PHD2, KIF1B }\end{array}$ & $\begin{array}{l}\text { A teljes kódoló szakasz PCR-t követő Sanger-szekvená- } \\
\text { lással és MLPA-val } \\
\text { *új generációs szekvenálással, validált génpanelek } \\
\text { bevezetése indokolt }\end{array}$ \\
\hline
\end{tabular}

$A I P=$ aryl interacting protein $C D C 73=$ ciklindependenskináz-73; $C D K N 1 B=$ ciklinfüggókináz-inhibitor-1B; FH = fumarát-hidratáz; GCM2 = gliasejt hiányzó homológ-2; GOT2 = glutamin-oxálecetsav-transzamináz; KIF1B = a kinezincsalád 1B-tagja; MAX = MYC-hez kapcsolódó faktor$\mathrm{X} ; \mathrm{MDH} 2$ = malát-dehidrogenáz-2; MLPA = multiplex ligatióspróba-amplifikáció; MTC = medullaris pajzsmirigyrák; NF1 = neurofibromatosis 1-es típusa; PHD2 = propil-hidroxiláz-domént tartalmazó fehérje-2; PTEN = foszfatáz- és tenzinhomológ; RET = transzfekció során újraszerveződő fehérje; SDHA = szukcinát-dehidrogenáz A-alegysége; SDHAF2 = szukcinát-dehidrogenáz AF2-alegysége; SDHB = szukcinát-dehidrogenáz B-alegysége; SDHC = szukcinát-dehidrogenáz C-alegysége; SDHD = szukcinát-dehidrogenáz D-alegysége; TMEM127 = transzmembránprotein-127; VHL = von Hippel-Lindau

neuroendokrin daganatok. Autoszomális domináns módon a Phaeo/PGL daganatok közel 35-40\%-a csírasejtes mutáció következményeként jelentkezik [19]. A már korábban bemutatásra került MEN2A- és MEN2B-szindróma részjelensége mellett a von Hippel-Lindau (VHL)betegség, a neurofibromatosis l-es típusa (NFl) és a familiaris paraganglioma szindrómák azok a kórképek, amelyekben Phaeo manifesztálódhat (2. táblázat).

A von Hippel-Lindau-szindróma egy komplex tumorszindróma, amelyben a Phaeo mellett a retina, a kisagy, a gerincvelő, a vese, míg ritkábban a hasnyálmirigy, a tüdő, a máj és a mellékvese területén alakulnak ki daganatok. Klinikai megjelenését tekintve a Phaeo kialakulásának valószínúsége alapján a VHL-szindrómát két fó altípusra osztják fel. Az l-es típusban a Phaeo igen alacsony valószínűséggel fordul elő, és a többi manifesztáció mind kialakulhat, míg a 2-es típus főkomponense a Phaeo. A 2A-típusban a világossejtes veserák kockázata alacsony, míg a 2B-típusban magas, de létezik egy 2C önálló entitás is, amelyben csak Phaeo jelenik meg [20].
Jelenleg több mint 800 különböző mutáció ismert a VHL-gén mutációs adatbázisa (www.umd.be/vhl) alapján. Bár ismertek genotípus-fenotípus összefüggések, a legtöbb VHL-szindrómás család egyéni fenotípust mutat. A VHL-szindróma l-es típusában jellemzően a fehérje hidrofób magját érintő misszensz és nonszensz mutációk, illetve deletiók fordulnak elö, melyek súlyosan károsodott, megrövidült fehérjéhez vezetnek, ezáltal teljes funkcióvesztést okoznak. Ezzel szemben a VHLszindróma 2-es típusában a misszensz típusú mutációk inkább a fehérjekötő helyeket érintik, s ezáltal részleges funkciókiesést okoznak. Az alternatív start kodonként szereplő 55. kodon előtti aminosavakat érintő (25., 38., 46., 52. kodon) mutációk patogenitása mérlegelendő [21], de Phaeo és komplett VHL-szindróma kialakulásával is összefüggésbe hozták óket (E46X és E52K).

A VHL-gén vizsgálata hagyományos molekuláris biológiai módszerekkel történik, PCR-reakciót követő Sanger-szekvenálással, és a $V H L$-gén heterozygota deletióinak kimutatására MLPA-módszer is szükséges. A VHL-gén patogén eltéréseinek 15-20\%-a tartozik abba a 
Phaeochromocytoma és paragangliomák hátterében azonosított géneltérések, az örökletes szindrómák, továbbá a gének felfedezésének időpontja

\begin{tabular}{lll}
\hline Gén & Szindróma & Leírásának ideje \\
\hline NF1 & Neurofibromatosis l-es típusa & 1990 \\
VHL & Von Hippel-Lindau & 1993 \\
RET & MEN-2 & 1993 \\
SDHD & PGL1 & 2000 \\
SDHB & PGL4 & 2000 \\
SDHC & PGL3 & 2000 \\
KIF1ß & Phaeo, neuroblastoma, tüdöcc. & 2008 \\
PHD2 & PGL, erythrocytosis & 2008 \\
SDHAF2 & PGL2 & 2009 \\
TMEM127 & Phaeo/PGL & 2010 \\
SDHA & Phaeo/PGL & 2010 \\
$M A X^{*}$ & Phaeo/PGL & 2011 \\
FH* & Phaeo & 2014 \\
MDH2* & Phaeo & 2015 \\
GOT2 & Phaeo & 2017 \\
\hline
\end{tabular}

* Felfedezésük exomszekvenálással történt.

FH = fumarát-hidratáz; GCM2 = gliasejt hiányzó homológ-2; GOT2 = glutamin-oxálecetsav-transzamináz; KIF1B = a kinezincsalád 1B-tagja; MAX = MYC-hez kapcsolódó faktor-X; MDH2 = malát-dehidro genáz-2; NF1 = neurofibromatosis 1 -es típusa; $\mathrm{PHD} 2$ = propil-hidroxiláz-domént tartalmazó fehérje-2; RET = transzfekció során újraszerveződő fehérje; SDHA = szukcinát-dehidrogenáz A-alegysége; SDHAF2 = szukcinát-dehidrogenáz AF2-alegysége; $\mathrm{SDHB}=$ szukcinát-dehidrogenáz B-alegysége; SDHC = szukcinát-dehidrogenáz Calegysége; SDHD = szukcinát-dehidrogenáz D-alegysége; TMEM127 = transzmembránprotein-127; VHL = von Hippel-Lindau;

csoportba, amelyhez szükséges MLPA- vagy valamilyen egyéb, géndózis kimutatására alkalmas módszer [22, 23 .

A VHL-gén szintén szerepel az új generációs szekvenálási panelekben, de a hemizigócia detektálása jelenleg ezzel a technológiával nem kellően kivitelezhető, főleg a PCR-amplifikálást használó könyvtárkészítések során ütközhetünk nehézségekbe [1].

A neurofibromatosis l-es típusában szintén várható Phaeo megjelenése, de az általában egyértelmű klinikai megjelenés, valamint az NFl-gén mérete korlátozta az NFl-gén hagyományos módszerekkel történő vizsgálatának elterjedését [1]. Jelenleg több új generációs szekvenálási génpanel alkalmazásával elérhető az NFl vizsgálata is.

Az örökletes Phaeo/paraganglioma (PGL) szindrómák hátterében álló gének azonosítása a 2000-es évek elején kezdődött, és tulajdonképpen jelenleg is tart (1. táblázat). Az ezredfordulón a Szent-Györgyi-Krebsciklus tagját képező szukcinát-dehidrogenáz (SDH) egyik alegységét kódoló SDHD-gén mutációját azonosították familiaris PGL-es családokban [24]. Még ebben az évben az $S D H B$ [25] és az SDHC [26] patogenetikai szerepét is igazolták. Mindezen eredmények alapján a familiaris megjelenésú PGL-ek 50-70\%-ában a sejtmagban kódolt $S D H B$-, $S D H C$ - és $S D H D$-gén csírasejtes mutációi állnak.

Az $S D H B$-, SDHC-és $S D H D$-génen kívül az elmúlt 8 évben további 9 gén betegségokozó mutációit azonosították örökletes paragangliomákban ( $S D H A-, S D H A F 2-$, FH-, KIF1B-, PHD2-, MAX-, TMEM127-, MDH2- és GOT2-gén-mutációk) [27-35]. A lehetséges betegségokozó gének nagy száma jelentően megnövelheti a genetikai vizsgálatok költségét és a munkaidőt, ezért elengedhetetlen az egyes gének vizsgálatának racionális megtervezése. Az Amerikai Endokrin Társaság szakmai ajánlása segít a vizsgálatok racionalizálásában. A fenotípusorientált algoritmus [36] szerint a MEN2 - és a VHLszindróma kizárása után a következő feladat az $S D H B$-, $S D H C$ - és $S D H D$-gén vizsgálata, amelyek közül a daganatok lokalizációja alapján dönthetünk a vizsgálatok sorrendjéről. SDHC-mutációt csak fej-nyak PGL-ben szenvedő betegekben mutattak ki; malignus paragangliomában szenvedő betegben elsőként az SDHB-gén vizsgálata javasolt [36].

Laboratóriumunkban, a különböző gének felismerésével összhangban, először egy RET-mutáció talaján kialakult MEN2-szindrómát ismertettünk 1999-ben [10], majd 2002-ben bizonyítottuk be, hogy a RET 609-es kodonjának mutációja következtében MEN2A-szindróma és Phaeo manifesztálódhat [11].

A hazai $V H L$-gén-eltérésekhez társuló klinikai manifesztációk ismertetésével kimutattuk, hogy az MLPAvizsgálat a hazai beteganyagban is mintegy $15 \%$-kal növelte a genetikai pozitív esetek számát [22], valamint a Ser80Leu-génvariáns patogenitását is egy nagy létszámú család részletes feldolgozásával bizonyítottuk [21].

Az újabban felfedezett gének szisztematikus vizsgálatát elvégezve 82 sporadikusnak vélt Phaeo/PGL betegben 11 esetben igazoltunk patogén eltérést, amelyek közül $4 S D H B$ - és 2 TMEM127-mutáció új mutáció volt. Érdekes eset volt egy TMEM127-mutációt hordozó ikerpár kórtörténete is, amely a szokatlan előfordulás miatt szintén unikális [37].

A 16 Phaeo/PGL gén közül 8 olyan fehérjét kódol, amelyek mitokondriális enzimként vagy enzim alegységeként funkcionálnak. A mutációk következtében kialakuló enzimdefektusok miatt felhalmozódó metabolitok megváltoztatják a sejtek anyagcseréjét, ami a sejtek túlélésére is hatással van. Ezeket a metabolitokat jelenleg mint onkometabolitokat tartják nyilván [38]. Sajnos a rutin laboratóriumi vizsgálatok közül ezek mennyiségi meghatározása jelenleg nem elérhető, nincs olyan eljárás, amellyel szürni lehetne a kóros metabolitprofilt vér- vagy vizeletmintákból. Daganatszövetből természetesen kimutatható pl. az SDH-mutációkra jellegzetes kóros szukcinát-fumarát arány, de szűrésre jelenleg ez az eljárás nem használható, ami azt jelenti, hogy továbbra is a genetikai szűrés jelenti a Phaeo/PGL-ek elsődleges szűrési stratégiáját. 
Az utóbbi évtizedben megjelent új generációs szekvenálási (NGS) módszerek a Phaeo és a PGL-ek tekintetében igazi sikertörténetek, hiszen a legutóbb azonosított 3 Phaeo/PGL gén $(M A X, F H$ és MDH2) felfedezése is ilyen technológiát alkalmazó exomszekvenálással történt [32-35].

A Semmelweis Egyetem II. Belgyógyászati Klinikája és az Endokrinológiai Genetikai Laboratórium a mindenkori legkorszerúbb diagnosztikus módszereket törekszik beépíteni a kutatás, valamint a mindennapi diagnosztika keretei közé. Munkacsoportunk kidolgozott egy génpanelt, amellyel a RET-, VHL-, NFI-, MEN1-, SDHA-, SDHB-, SDHC-, SDHD-, SDHAF2-, KIFlB-, MAX-, TMEM127-, PHD2-, FH-, EPAS1-gén egyidejúleg vizsgálható. A módszer analitikai teljesítőképességének értékelése során vizsgálni kell mind a könyvtárkészítés, mind pedig a bioinformatikai adatfeldolgozás teljesítőképességét. Mutációt hordozó és mutációt nem hordozó esetek bevonásával a módszervalidáláshoz szükséges idő rövidíthető ugyan, de természetesen minden génre meg kell határozni a szenzitivitás- és specificitásértékeket, amihez ellenőrző Sanger-szekvenálások szükségesek. A Phaeo/ PGL-ek vizsgálatában alkalmazott amplikonszekvenálások feldolgozása kimutatta, hogy az eddig ismertetett egyik módszer sem biztosította a 100\%-os szenzitivitást és specificitást, aminek okai elsősorban a bioinformatikai elemzések voltak [1]. Ezek az eredmények indokolják azokat a szakmai irányelveket, amelyek arra hívják fel a figyelmet, hogy a klinikai döntéshozatalban figyelembe vett NGS-alapú mérések eredményeit több bioinformatikai elemzéssel kell ellenőrizni és az eredményeket hagyományos molekuláris biológiai módszerekkel szükséges megerősíteni $[39,40]$.

A génpanelek szekvenálása mellett az exomszekvenálás terjedése még inkább indokolja, hogy fokozott figyelmet kell fordítani a módszertani kérdésekre, és számos validálási lépésnek kell megelőznie a vizsgálati lelet kiadását. A legtöbb klinikai genetikai vizsgálatot végző laboratórium az exomszekvenálást mint komplex szűrővizsgálatot alkalmazza, és saját, validált munkafolyamataival egészíti ki ezeket [1, 39].

\section{Következtetések}

A molekuláris genetikai vizsgálatok alkalmazása a klinikai gyakorlatban átalakulóban van. Ennek oka, hogy az új generációs szekvenálási módszereken alapuló vizsgálatok kedvező fajlagos költségcsökkenést és - az egyre növekvő információállomány birtokában - gén- vagy akár mutációspecifikus betegellátást tesz lehetővé. A hormonrendszer daganatainak jelentős része visszavezethető egy-egy örökletes géndefektusra, ugyanakkor a monogénes szindrómák előfordulási gyakorisága nagyon alacsony, ami nehezíti a betegek felismerését. A gyakoribb előfordulású, a mellékpajzsmirigyből, a mellékvesevelőből vagy a paraganglionokból kiinduló daganatok esetében fokozott jelentőségü a genetikai tényezők szerepe, ami nemcsak diagnosztikai szempontból fontos, de terápiás következményeket is jelent a betegeknek és családtagjaiknak. Az új generációs szekvenáláson alapuló módszereknek a klinikai genetikai gyakorlatba történő beépülésével elérhető ezeknek a daganatoknak a precíz jellemzése, molekuláris kategorizálása. Ezeknek a vizsgálatoknak a klinikai diagnosztikába történő bevezetése előtt szükséges a módszerek technikai validálása és teljesítőképességük felmérése. A metodikából eredően a genetikai vizsgálatokat megelőző genetikai tanácsadás folyamata, a beteg-beleegyező nyilatkozatok átdolgozása szintén szükséges ahhoz, hogy a vizsgálatok megfeleljenek a jelenleg hatályos etikai, jogi és adatvédelmi szabályoknak. Az orvosszakmai társaságok, valamint az európai és helyi adatvédelmi ajánlások, iránymutatások megismerése és ezeknek a napi gyakorlatba történő bevezetése a közeljövő feladata lesz.

Anyagi támogatás: E munkát a Nemzeti Kutatási Fejlesztési és Innovációs Hivatal Nemzeti Bionika Program dr. Patócs Attila által elnyert K125231. számú pályázata támogatta.

Szerzői munkamegosztás: S. B., G. V. K., K. A., B. H., L. I., I. P., Ny. G., P. A.: A téma kidolgozása. S. B., G. V. K., P. A.: A kézirat összeállítása. L. I.: Az új generációs szekvenálásról szóló rész kidolgozása. I. P. Klinikai genetikai összefüggések kidolgozása. A cikk végleges változatát valamennyi szerző elolvasta és jóváhagyta.

Érdekeltségek: A szerzőknek nincsenek érdekeltségeik.

\section{Köszönetnyilvánítás}

A szerzők köszönettel és hálával gondolnak Rácz Károly professzor úrra, aki megteremtette hazánkban az örökletes endokrinológiai tumor szindrómák molekuláris genetikai vizsgálatainak lehetőségét. A szerzők köszönetüket fejezik ki Tóth Miklós, Szücs Nikolett, Kiss Róbert, Sallai Ágnes, Halász Zita, Török Dóra, Somogyi Anikó, Valkusz Zsuzsanna, Lakatos Péter, Kovács Gábor László, Csajbók Éva, Tóth Géza, Nagy Endre és Mezösi Emese klinikuskollégáknak a betegek klinikai ellátásáért.

\section{Irodalom}

[1] Patócs A, Likó I, Butz H, et al. Novel methods and their applicability in the evaluation of the genetic background of endocrine system tumours. [Új módszertani lehetőségek és ezek alkalmazása a hormonális rendszer daganatainak genetikai kivizsgálásában.] Orv Hetil. 2015; 156: 2063-2069. [Hungarian]

[2] Robson ME, Bradbury AR, Arun B, et al. American Society of Clinical Oncology Policy statement update: genetic and genomic testing for cancer susceptibility. J. Clin Oncol. 2015; 33: 36603667

[3] Toledo RA, Dahia PL. Next-generation sequencing for the diagnosis of hereditary pheochromocytoma and paraganglioma syndromes. Curr Opin Endocrinol Diabetes Obes. 2015; 22: 169179.

[4] Agarwal SK, Kester MB, Debelenko LV, et al. Germline mutations of the $M E N 1$ gene in familial multiple endocrine neoplasia type 1 and related states. Hum Mol Genet. 1997; 6: 1169-1175. 
[5] Choi H, Kim S, Moon JH, et al. Multiple endocrine neoplasia type 1 with multiple leiomyomas linked to a novel mutation in the MENl gene. Yonsei Med J. 2008; 49: 655-661.

[6] Thakker RV, Newey PJ, Walls GV, et al. Clinical practice guidelines for multiple endocrine neoplasia type 1 (MEN1). J Clin End Met. 2012; 97: 2990-3011.

[7] Balogh K, Hunyady L, Patocs A, et al. MENI gene mutations in Hungarian patients with multiple endocrine neoplasia type 1 . Clin Endocrinol. 2007; 67: 727-734.

[8] Mulligan LM, Kwok JB, Healey CS, et al. Germ-line mutations of the RET proto-oncogene in multiple endocrine neoplasia type 2A. Nature 1993; 363: 458-460.

[9] Wells SA Jr, Asa SL, Dralle H, et al. Revised American Thyroid Association guidelines for the management of medullary thyroid carcinoma: The American Thyroid Association Guidelines Task Force on Medullary Thyroid Carcinoma. Thyroid 2015; 25: 567-610.

[10] Igaz P, Rácz K, Tóth M, et al. Ret-protooncogene mutation, verified by molecular genetic methods, in a Hungarian MEN Type 2a family. [Molekuláris genetikai módszerekkel igazolt retprotoonkogén mutáció magyar MEN2A család esetében.] Orv Hetil. 1999; 140: 355-357. [Hungarian]

[11] Igaz P, Patocs A, Racz K, et al. Occurrence of pheochromocytoma in a MEN2A family with codon 609 mutation of the RET proto-oncogene. J Clin Endocrinol Metab. 2002; 87: 2994.

[12] Patocs A, Klein I, Szilvasi A, et al. Genotype-phenotype correlations in Hungarian patients with hereditary medullary thyroid cancer. Wien Klin Wochenschr. 2006; 118: 417-421.

[13] Molatore S, Pellegata NS. The MENX syndrome and p27: relationships with multiple endocrine neoplasia. Prog Brain Res. 2010; 182: 295-320.

[14] van der Tuin K, Tops CM, Adank MA, et al. CDC73-related disorders: clinical manifestations and case detection in primary hyperparathyroidism. J Clin Endocrinol Metab. 2017; 102: $4534-4540$

[15] Guan B, Welch JM, Sapp JC, et al. GCM2-activating mutations in familial isolated hyperparathyroidism. Am J Hum Genet. 2016; 99: 1034-1044.

[16] Guan B, Welch JM, Vemulapalli M, et al. Ethnicity of patients with germline GCM2-activating variants and primary hyperparathyroidism. J Endocr Soc. 2017; 1: 488-499.

[17] Papadakis M, Meurer N, Margariti T, et al. A novel mutation of the calcium-sensing receptor gene in a German subject with familial hypocalciuric hypercalcemia and primary hyperparathyroidism. Hormones (Athens) 2016; 15: 557-559.

[18] Toke J, Patocs A, Balogh K, et al. Parathyroid hormone-dependent hypercalcemia. Wien Klin Wochenschr. 2009; 121: 236-245.

[19] Neumann HP, Bausch B, McWhinney SR, et al. Germ-line mutations in nonsyndromic pheochromocytoma. N Engl J Med. 2002; 346: 1459-1466.

[20] Latif F, Tory K, Gnarra J, et al. Identification of the von Hippel-Lindau disease tumor suppressor gene. Science 1993; 260: $1317-1320$

[21] Patocs A, Gergics P, Balogh K, et al. Ser80Ile mutation and a concurrent Pro25Leu variant of the VHL gene in an extended Hungarian von Hippel-Lindau family. BMC Med Genet. 2008; 9: 29.

[22] Gergics P, Patocs A, Toth M, et al. Germline $V H L$ gene mutations in Hungarian families with von Hippel-Lindau disease and patients with apparently sporadic unilateral pheochromocytomas. Eur J Endocrinol. 2009; 161: 495-502.

[23] Gergics P, Tóke J, Szilágyi A, et al. Methods for the analysis of large gene deletions and their application in some monogenic disorders. [A nagy géndeletiók kimutatásának módszerei és alkalmazásuk egyes örökletes betegségekben.] Orv Hetil. 2009; 150: 2258-2264. [Hungarian]

[24] Baysal BE, Ferrell RE, Willett-Brozick JE, et al. Mutations in $S D H D$, a mitochondrial complex II gene, in hereditary paraganglioma. Science 2000; 287: 848-851.

[25] Astuti D, Latif F, Dallol A, et al. Gene mutations in the succinate dehydrogenase subunit SDHB cause susceptibility to familial pheochromocytoma and to familial paraganglioma. Am J Hum Genet. 2001; 69: 49-54.

[26] Niemann S, Muller U. Mutations in SDHC cause autosomal dominant paraganglioma, type 3. Nat Genet. 2000; 26: 268270.

[27] Yeh IT, Lenci RE, Qin Y, et al. A germline mutation of the KIF1B $\beta$ gene on 1 p36 in a family with neural and nonneural tumors. Hum Genet. 2008; 124: 279-285.

[28] Ladroue C, Carcenac R, Leporrier M, et al. PHD2 mutation and congenital erythrocytosis with paraganglioma. N Engl J Med. 2008; 359: 2685-2692.

[29] Hao HX, Khalimonchuk O, Schraders M, et al. SDH5, a gene required for flavination of succinate dehydrogenase, is mutated in paraganglioma. Science 2009; 325: 1139-1142.

[30] Qin Y, Yao L, King EE, et al. Germline mutations in TMEM127 confer susceptibility to pheochromocytoma. Nat Genet. 2010; 42: 229-233.

[31] Burnichon N, Briere JJ, Libe R, et al. SDHA is a tumor suppressor gene causing paraganglioma. Hum Mol Genet. 2010; 19: 3011-3020.

[32] Clark GR, Sciacovelli M, Gaude E, et al. Germline FH mutations presenting with pheochromocytoma. J Clin Endocrinol Metab. 2014; 99: E2046-E2050.

[33] Remacha L, Comino-Méndez I, Richter S, et al. Targeted exome sequencing of krebs cycle genes reveals candidate cancer-Predisposing mutations in pheochromocytomas and paragangliomas. Clin Cancer Res. 2017; 23: 6315-6324.

[34] Comino-Méndez I, Gracia-Aznárez FJ, Schiavi F, et al. Exome sequencing identifies $M A X$ mutations as a cause of hereditary pheochromocytoma. Nat Genet. 2011; 43: 663-667.

[35] Cascón A, Comino-Méndez I, Currás-Freixes $M$, et al. Wholeexome sequencing identifies $M D H 2$ as a new familial paraganglioma gene. J Natl Cancer Inst. 2015; 107: djv053.

[36] Lenders JW, Duh QY, Eisenhofer G, et al. Pheochromocytoma and paraganglioma: an Endocrine Society clinical practice guideline. J Clin Endocrinol Met. 2014; 99: 1915-1942.

[37] Patocs A, Lendvai NK, Butz $\mathrm{H}$, et al. Novel $S D H B$ and TMEM127 mutations in patients with pheochromocytoma/paraganglioma syndrome. Pathol Oncol Res. 2016; 22: 673-679.

[38] Lendvai N, Pawlosky R., Bullova P, et al. Succinate-to-fumarate ratio as a new metabolic marker to detect the presence of $S D H B / D$-related paraganglioma: initial experimental and ex vivo findings. Endocrinology 2014; 155: 27-32.

[39] van El CG, Cornel MC, Borry P, et al. Whole-genome sequencing in health care: recommendations of the European Society of Human Genetics. Eur J Hum Genet. 2013; 21: 580-584.

[40] DePristo MA, Banks E, Poplin RE, et al. A framework for variation discovery and genotyping using next-generation DNA sequencing data. Nat Genet. 2011; 43: 491-498.

(Patócs Attila dr., Budapest, Szentkirályi u. 46., 1088 e-mail: patocs.attila@med.semmelweis-univ.hu) 